\title{
Reclassification of Lactobacillus ferintoshensis as a later heterotypic synonym of Lactobacillus parabuchneri
}

\author{
Marc Vancanneyt, Katrien Engelbeen, Marjan De Wachter, \\ Katrien Vandemeulebroecke, Ilse Cleenwerck and Jean Swings \\ BCCM/LMG Bacteria Collection, Ghent University, K. L. Ledeganckstraat 35, B-9000 Ghent, \\ Belgium
}

Correspondence

Marc Vancanneyt

Marc.Vancanneyt@rug.ac.be

\begin{abstract}
Lactobacillus ferintoshensis has recently been described as a novel species, distinct from its close phylogenetic neighbours Lactobacillus buchneri, Lactobacillus kefiri and Lactobacillus hilgardii. Two highly related species with validly published names, Lactobacillus parakefiri and Lactobacillus parabuchneri, were not considered in the study due to the lack of 16S rRNA gene sequence data at that time. Since the publication of the study, the sequences have become available and have revealed that $L$. ferintoshensis and $L$. parabuchneri share $99 \cdot 7 \% 16 \mathrm{~S}$ rRNA gene sequence similarity. Further genomic and phenotypic data, derived from fluorescent amplified fragment length polymorphism, DNA-DNA hybridization and API $50 \mathrm{CHL}$ analyses, have demonstrated that the species are synonymous.
\end{abstract}

Lactobacillus ferintoshensis, isolated from Scotch malt whisky distilleries, was described by Simpson et al. (2001) based on three strains, the type strain $\mathrm{R} 7-84^{\mathrm{T}}$ (=LMG $22038^{\mathrm{T}}=$ CIP $106749^{\mathrm{T}}$ ), strain R7-9 and strain R15-103. The type strain was compared with Lactobacillus buchneri, Lactobacillus kefiri and Lactobacillus hilgardii, its nearest phylogenetic neighbours, showing $98 \cdot 4,98 \cdot 1$ and $97 \cdot 3 \% 16 \mathrm{~S}$ rRNA gene sequence similarities, respectively. DNA-DNA hybridizations and further phenotypic characterization demonstrated that $L$. ferintoshensis represented a novel species. In their study, however, the authors did not include two related species, Lactobacillus parabuchneri (Farrow et al., 1988) and Lactobacillus parakefiri (Takizawa et al., 1994), which were species with validly published names at that time but lacked publicly available $16 \mathrm{~S}$ rRNA gene sequence data. Subsequent sequence analysis demonstrated a very high similarity of $99 \cdot 7 \%$ between $L$. ferintoshensis and L. parabuchneri (see below). In the present study, the relatedness between the latter two species was studied and indicated that there was synonymy between the two taxa.

Two reference strains of L. ferintoshensis, LMG $22038^{\mathrm{T}}$ and strain R15-103, both isolated from a whisky distillery, were included in this study. The latter strain R15-103 (assigned as LMG 22462) was received from F. G. Priest (Heriot-Watt

Published online ahead of print on 27 May 2005 as DOI 10.1099/ ijs.0.63779-0.

Abbreviation: FAFLP, fluorescent amplified fragment length polymorphism.

The GenBank/EMBL/DDBJ accession number for the 16S rRNA gene sequence of Lactobacillus parabuchneri LMG $11457^{\top}$ is AJ970317.
University, Edinburgh, UK), the corresponding author for the L. ferintoshensis paper. For L. parabuchneri, strains LMG $11457^{\mathrm{T}}$ and LMG 11973, isolated from human saliva and brewery yeast, respectively, were selected for further comparative study. L. ferintoshensis strains were cultivated and maintained on de Man, Rogosa and Sharpe (MRS) medium supplemented with $0.5 \%$ maltose and incubated aerobically at $28^{\circ} \mathrm{C}$. L. parabuchneri strains and other reference strains studied were cultivated and maintained on MRS medium and incubated anaerobically at $37^{\circ} \mathrm{C}$, unless indicated otherwise.

The phylogenetic relatedness between the type strains of $L$. ferintoshensis and L. parabuchneri was investigated. For the latter strain, only a partial sequence of 1219 bp was available at GenBank/EMBL and so a nearly complete $16 \mathrm{~S}$ rRNA gene sequence was determined in this study. Genomic DNA from LMG $11457^{\mathrm{T}}$ was prepared according to the protocol of Niemann et al. (1997). 16S rRNA gene amplification, purification and sequencing was performed as described by Vancanneyt et al. (2004) with the following modifications: PCR-amplified 16S rRNAs were purified by using a NucleoFast 96 PCR clean-up kit (Macherey-Nagel). Sequencing reactions were performed by using a BigDye terminator cycle sequencing kit (Applied Biosystems) and purified using a Montage $\mathrm{SEQ}_{96}$ sequencing reaction cleanup kit (Millipore). Electrophoresis of sequence reaction products was performed using an ABI Prism 3100 Genetic Analyzer (Applied Biosystems). Sequence assembly was carried out with the AutoAssembler program (Applied Biosystems). The 16S rRNA gene sequence of $L$. parabuchneri LMG $11457^{\mathrm{T}}$, a continuous stretch of $1527 \mathrm{bp}$, was 
determined and was aligned with the sequence of the type strain of $L$. ferintoshensis, retrieved from GenBank/EMBL. A phylogenetic tree was constructed by the neighbour-joining method using the BioNumerics software package, version 3.5 (Applied Maths). Unknown bases were discarded for the analyses. Bootstrapping analysis was undertaken to test the statistical reliability of the topology of the neighbourjoining tree using 500 bootstrap resamplings of the data (Fig. 1). A comparison of the sequences of the type strains of L. ferintoshensis and L. parabuchneri revealed $99 \cdot 7 \%$ sequence similarity.

L. ferintoshensis LMG $22038^{\mathrm{T}}$ and LMG 22462 were investigated using fluorescent amplified fragment length polymorphism (FAFLP) fingerprinting of whole genomes and the patterns obtained were compared with those of related taxa. FAFLP fingerprinting was performed as described by Thompson et al. (2001) with the following modifications: EcoRI/TaqI was used as the restriction enzyme combination and the primer combination E01/T01 (both having an adenosine extension at the 3 -end) was applied for selective PCR. The resulting electrophoretic patterns were tracked and normalized using GENESCAN 3.1 software (Applera). Normalized tables of peaks, containing fragments of 50 to $536 \mathrm{bp}$, were transferred into the BioNumerics software package, version 3.5 and the computer-generated fingerprints were added to an existing database of FAFLP fingerprints of lactic acid bacteria at the BCCM/LMG Bacteria Collection. For numerical analysis, data between the 75 and 500 bp bands of the internal standard were used. Clustering was performed using a Dice coefficient and the UPGMA algorithm. The FAFLP fingerprints of the two strains were compared with reference profiles of lactic acid bacteria taxa as currently available from the BCCM/LMG database. FAFLP analysis revealed a high similarity between $L$.

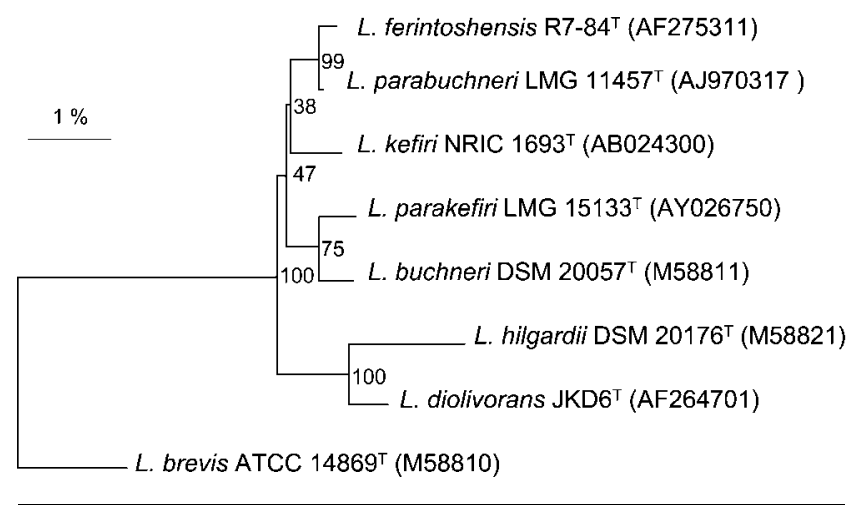

Fig. 1. Distance matrix tree showing the phylogenetic relationships of $L$. ferintoshensis and $L$. parabuchneri and other reference species belonging to the $L$. buchneri group, based on $16 S$ rRNA gene sequence comparisons. Lactobacillus brevis was used as the outgroup and bootstrap values (percentages of 500 tree replications) are indicated at branch points. Bar, $1 \%$ sequence divergence. ferintoshensis and L. parabuchneri. Fig. 2 shows a dendrogram in which L. ferintoshensis and L. parabuchneri strains were found to be grouped in a single cluster and separated from related reference species.

DNA G $+\mathrm{C}$ content was determined for the L. ferintoshensis and L. parabuchneri strains. DNA was extracted from $0 \cdot 75$ $1.25 \mathrm{~g}$ (wet weight) according to the protocol described by Gevers et al. (2001), using a combination of glass beads and enzymes (for LMG 11973, mutanolysin was added to a final concentration of $750 \mathrm{U} \mathrm{ml}^{-1}$ ) but with the following modifications. Volumes were increased by $10 \times$ for use on a large scale. The SDS-treated cells were vortexed with beads for $30 \mathrm{~s}$. After the addition of $16.5 \mathrm{ml}$ buffer ( $10 \mathrm{mM}$ Tris/ $\mathrm{HCl}, 100 \mathrm{mM}$ EDTA, $\mathrm{pH} \mathrm{8.0)} \mathrm{and} 5 \mathrm{ml} 5 \mathrm{M} \mathrm{NaCl}$, followed by gentle shaking, the suspension was incubated at $65^{\circ} \mathrm{C}$ for $10 \mathrm{~min}$. Subsequent chloroform/isoamylalcohol extraction, precipitation, spooling of DNA onto a glass rod, washing with ethanol and RNase treatment were performed as described by Marmur (1961). After RNase treatment, proteinase $\mathrm{K}\left(1 \mathrm{mg} \mathrm{ml}^{-1}\right.$; Merck) was added to the mixture. For the determination of DNA G $+\mathrm{C}$ content, DNA was degraded enzymically into nucleosides as described by Mesbah et al. (1989). The nucleoside mixture was then separated by HPLC using a Waters SymmetryShield C8 column maintained at a temperature of $37^{\circ} \mathrm{C}$. The solvent used comprised $0.02 \mathrm{M}\left(\mathrm{NH}_{4}\right) \mathrm{H}_{2} \mathrm{PO}_{4}(\mathrm{pH} 4.0)$ with $1.5 \%$ acetonitrile. Non-methylated lambda phage DNA (Sigma) was used as the calibration reference. DNA G $+\mathrm{C}$ content of all four strains was $43 \mathrm{~mol} \%$. This value was close to the value of $44 \mathrm{~mol} \%$ determined for the type strain of $L$. parabuchneri (Farrow et al., 1998).

DNA-DNA hybridizations were performed between $L$. ferintoshensis LMG $22038^{\mathrm{T}}$ and LMG 22462, and between L. parabuchneri LMG $11457^{\mathrm{T}}$ and LMG 11973 (DNA was prepared as described above). The microplate method was used as described by Ezaki et al. (1989) and Goris et al. (1998), using an HTS7000 Bio Assay Reader (Perkin Elmer) for fluorescence measurements. Biotinylated singlestranded (ss) DNA was hybridized with unlabelled ssDNA, which was bound non-covalently to microplate wells. Hybridizations were performed at $39^{\circ} \mathrm{C}$ in a hybridization mixture containing $2 \times$ SSC, $5 \times$ Denhardt's solution, $2.5 \%$ dextran sulphate, $50 \%$ formamide, $100 \mu$ g denatured salmon sperm DNA ml ${ }^{-1}$ and $1.25 \mu \mathrm{g}$ biotinylated DNA probe $\mathrm{ml}^{-1}$. The DNA-DNA hybridization level between the four strains was in a range of 77 to $93 \%$; indicating that the two species actually constitute a single species. Strain LMG 22462 which showed a high binding level (73\%) with the type strain of the species under non-stringent conditions and intermediate levels ( $44 \%$ ) under stringent conditions in Simpson et al. (2001), demonstrated a binding level of $93 \%$ to the type strain of $L$. ferintoshensis in our experiments.

Growth characteristics and biochemical features were investigated with cells grown on MRS agar supplemented with maltose after $24 \mathrm{~h}$ incubation at $28^{\circ} \mathrm{C}$ under aerobic conditions. Carbohydrate fermentation tests were carried out 


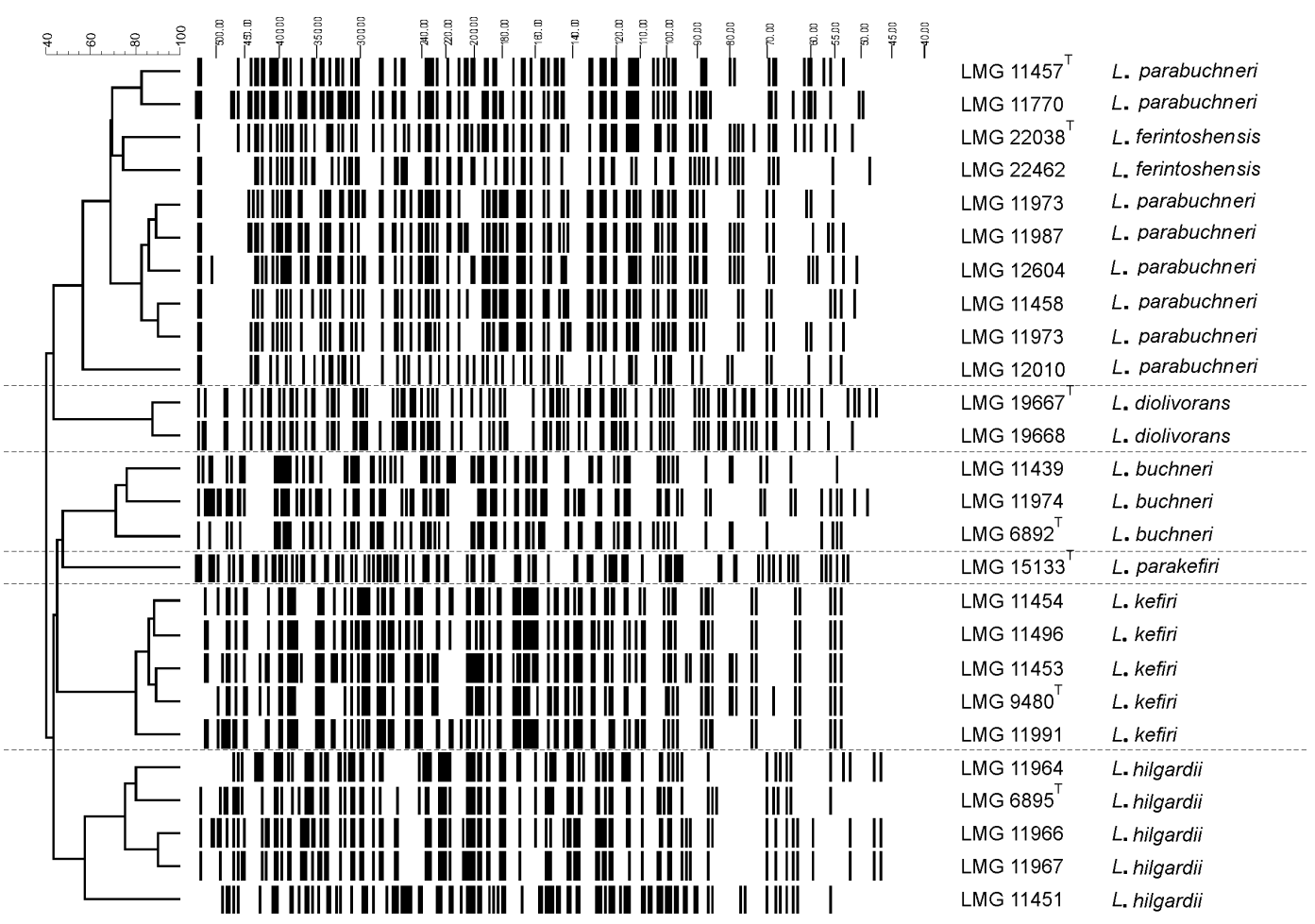

Fig. 2. FAFLP patterns and corresponding dendrogram, derived from the UPGMA linkage of Dice coefficients (expressed as a percentage value for convenience) of $L$. ferintoshensis and $L$. parabuchneri strains and related reference strains.

using the API 50 CHL galleries according the manufacturer's instructions (bioMérieux). Acid is produced from L-arabinose, D-fructose, galactose, gluconate, D-glucose, maltose, melezitose, melibiose, ribose and sucrose. No acidification of adonitol, amygdalin, D-arabinose, Darabitol, L-arabitol, arbutin, cellobiose, dulcitol, erythritol, aesculin, D-fucose, L-fucose, $\beta$-gentiobiose, 2-ketogluconate, $\mathrm{N}$-acetylglucosamine, methyl $\alpha$-D-glucoside, glycerol, glycogen, inositol, inulin, lactose, mannitol, D-mannose, methyl $\alpha$-D-mannoside, D-lyxose, D-raffinose, rhamnose, salicin, sorbitol, L-sorbose, starch, D-tagatose, trehalose, Dturanose, xylitol, D-xylose, L-xylose or methyl $\beta$-xyloside are observed. Acid production from 5-ketogluconate is variable and is only weakly positive for the type strain of $L$. parabuchneri. These data are in agreement with the data of Farrow et al. (1988), except for acid formation of Draffinose, which could not be confirmed.

The data from the present study show that $L$. ferintoshensis strains belong to the species $L$. parabuchneri. Consequently, L. ferintoshensis Simpson et al. 2002 is a later heterotypic synonym of L. parabuchneri Farrow et al. 1989.

\section{Acknowledgements}

This research was supported by the Prime Minister's Services, Federal Office for Scientific, Technical and Cultural Affairs, Belgium.

\section{References}

Ezaki, T., Hashimoto, Y. \& Yabuuchi, E. (1989). Fluorometric deoxyribonucleic acid-deoxyribonucleic acid hybridization in microdilution wells as an alternative to membrane filter hybridization in which radioisotopes are used to determine genetic relatedness among bacterial strains. Int J Syst Bacteriol 39, 224-229.

Farrow, J. A. E., Phillips, B. A. \& Collins, M. D. (1988). Nucleic acid studies on some heterofermentative lactobacilli: description of Lactobacillus malefermentans sp. nov. and Lactobacillus parabuchneri sp. nov. FEMS Microbiol Lett 55, 163-168.

Gevers, D., Huys, G. \& Swings, J. (2001). Applicability of rep-PCR fingerprinting for identification of Lactobacillus species. FEMS Microbiol Lett 205, 31-36.

Goris, J., Suzuki, K., De Vos, P., Nakase, T. \& Kersters, K. (1998). Evaluation of a microplate DNA-DNA hybridization method compared with the initial renaturation method. Can J Microbiol 44, 1148-1153.

Marmur, J. (1961). A procedure for the isolation of deoxyribonucleic acid from microorganisms. J Mol Biol 3, 208-218.

Mesbah, M., Premachandran, U. \& Whitman, W. B. (1989). Precise measurement of the $\mathrm{G}+\mathrm{C}$ content of deoxyribonucleic acid by high-performance liquid chromatography. Int J Syst Bacteriol 39, 159-167.

Niemann, S., Puehler, A., Tichy, H.-V., Simon, R. \& Selbitschka, W. (1997). Evaluation of the resolving power of three different DNA fingerprinting methods to discriminate among isolates of a natural Rhizobium meliloti population. J Appl Microbiol 82, 477-484.

Simpson, K. L., Pettersson, B. \& Priest, F. G. (2001). Characterization of lactobacilli from Scotch malt whisky distilleries and 
description of Lactobacillus ferintoshensis sp. nov., a new species isolated from malt whisky fermentations. Microbiology 147, 1007-1016.

Takizawa, S., Kojima, S., Tamura, S., Fujinaga, S., Benno, Y. \& Nakase, T. (1994). Lactobacillus kefirgranum sp. nov. and Lactobacillus parakefir sp. nov., two new species from kefir grains. Int J Syst Bacteriol 44, 435-439.

Thompson, F. L., Hoste, B., Vandemeulebroecke, K. \& Swings, J.

(2001). Genomic diversity amongst Vibrio isolates from different sources determined by Fluorescent Amplified Fragment Length Polymorphism. Syst Appl Microbiol 24, 520-538.

Vancanneyt, M., Mengaud, J., Cleenwerck, I., Hoste, B., Dawyndt, P., Degivry, M. C., Ringuet, D., Janssens, D. \& Swings, J. (2004). Reclassification of Lactobacillus kefirgranum Takizawa et al. 1994 as Lactobacillus kefiranofaciens subsp. kefirgranum subsp. nov. and emended description of L. kefiranofaciens Fujisawa et al. 1988. Int J Syst Evol Microbiol 54, 551-556. 